\title{
PRODUCTION OF TITANIUM-BASED ALLOYS BY METALLOTHERMIC REDUCTION OF OXIDE TITANIUM-CONTAINING RAW MATERIALS
}

\author{
${ }^{1}$ Victor PROTSENKO, ${ }^{2}$ Yulia BONDARENKO, ${ }^{3}$ Dmytro KRUGLYAK, ${ }^{4}$ Aleksei KIRICHENKO, \\ ${ }^{4}$ Oksana VODENNIKOVA \\ 1,2,3,4,5 Zaporizhzhia National University, Zaporizhzhia, Ukraine, \\ 1.protsenkovm@yahoo.com, ㄹuvbondarenko.1984@gmail.com, 33krugly1987@gmail.com, \\ 4smeagerl@gmail.com, ${ }^{5}$ oksana vodennikova@ukr.net
}

https://doi.org/10.37904/metal.2021.4261

\begin{abstract}
The purpose of this work is to investigate the structure formation in intermetallic alloys by metallothermic reduction of oxide titanium-containing raw materials. The diagram feature of the state of the TiAl system is that a whole spectrum of intermetallic compounds is formed in it: two intermetallic compounds with wide homogeneity regions $\left(\alpha_{2}-\mathrm{Ti}_{3} \mathrm{Al}, \mathrm{y}-\mathrm{TiAl}\right)$, two intermetallic compounds with narrow homogeneity regions $\left(\mathrm{TiAl}_{2}\right.$ and $\mathrm{TiAl}_{3}$ ) and a number of metastable phases. The high cost of commercial titanium alloys used in products for aerospace, military and medical purposes prompts manufacturers to search for ways to obtain alloys for civilian use, which are not so high purity in terms of impurity content, but which have lower cost. Methods for producing titanium in the form of alloys with aluminum and iron by metallothermic reduction of titaniumcontaining oxide raw materials are considered. It is shown that these alloys can be successfully used in many areas of industry, under conditions of a decrease in the amount of titanium waste, which is obtained by traditional chloride technology.
\end{abstract}

Keywords: Intermetallic alloy, aluminothermal process, raw materials, oxide titanium, structure

\section{INTRODUCTION}

The traditional chloride technology of titanium production is complex, multi-conversion and energy-consuming, therefore, the development of alternative methods for producing cheaper titanium is currently a very promising, actively developing direction [1].

The purpose of the current work is to develop methods for producing relatively cheap titanium-based alloys (Ti-Al, Ti-Fe) by metallothermic reduction of titanium-containing oxide raw materials. The specific properties of titanium, and, above all, its high affinity for carbon, nitrogen and oxygen, make it an indispensable alloying element in the production of ferrous metals [2,3]. An even more significant improvement in mechanical properties is achieved when processing steel and cast iron with titanium together with other elements $(\mathrm{Al}, \mathrm{Mn}$, $\mathrm{Si}, \mathrm{B}, \mathrm{Ca}$, etc.) $[2,4]$. Using flux-cored wire and powder injection into the melt is much more efficient than using titanium in the form of a sponge, which oxidizes on the surface of the steel melt. In this case, the titanium waste reaches $45-65 \%$ [5]. Ti-Al alloys are widely used in alloying and modifying aluminum and its alloys [6], in production of valves in automobile engines $[7,8]$, as heat-resistant, corrosion-resistant and wear-resistant coatings [9,10], and as a filler material for arc welding [11], since titanium aluminides are easily crushed to a powdery state. Titanium aluminides are also used for the manufacture of catalysts [12], getters and Raschig rings for rectification columns [13], as a reducing agent in metallothermic processes in the preparation of ligatures for titanium alloys [2], as additives to carbon-graphite materials to improve the crystal structure and so on. Pure titanium can be obtained from the Ti-Al alloy using subchloride technology [3]. 


\section{RESULTS OF THE STUDY}

The diagram feature of the state of the TiAl system is that a whole spectrum of intermetallic compounds is formed in it: two intermetallic compounds with wide homogeneity regions $\left(\alpha_{2}-\mathrm{Ti}_{3} \mathrm{Al}, \mathrm{\gamma}-\mathrm{TiAl}\right)$, two intermetallic compounds with narrow homogeneity regions $\left(\mathrm{TiAl}_{2}\right.$ and $\left.\mathrm{TiAl}_{3}\right)$ and a number of metastable phases.

Thermodynamic calculations of the stability of intermetallic compounds, as well as other chemical compounds, are based on the use of the Gibbs-Helmholtz equations. The calculations were carried out in a wide temperature range. The standard temperature of $298 \mathrm{~K}$ was chosen as an initial temperature, and the final temperature was the maximum melting point of intermetallic compounds ( $2000 \mathrm{~K})[9$, 5]. For each intermetallic compound in this temperature range, the value was calculated with a step of $\sim 200 \mathrm{~K}$. The value of the thermodynamic functions was also determined at the melting temperature of aluminum (933 K). For some compounds, calculations were carried out using the TERRA program, which consists of an information fund and contains information about the thermodynamic properties of individual substances and a set of programs that calculate the parameters of the equilibrium state of chemically reacting systems. The performed calculations of the change in the Gibbs free energy $\Delta G$ during the formation of various aluminides from aluminum and titanium showed that $\mathrm{TiAl}_{3}$ has the lowest energy among stable intermetallic compounds in the entire temperature range (Figure 1). The $\Delta G$ is somewhat lower for the metastable phases of $\mathrm{TiAl}_{2}$ and $\mathrm{Ti}_{2} \mathrm{Al}_{5}$, but they can form only through several intermediate reactions of TiAl transformation, which is thermodynamically unlikely. In other words, the phase compositions of the synthesized $\mathrm{y}$-TiAl alloys correspond to the composition established in [5].

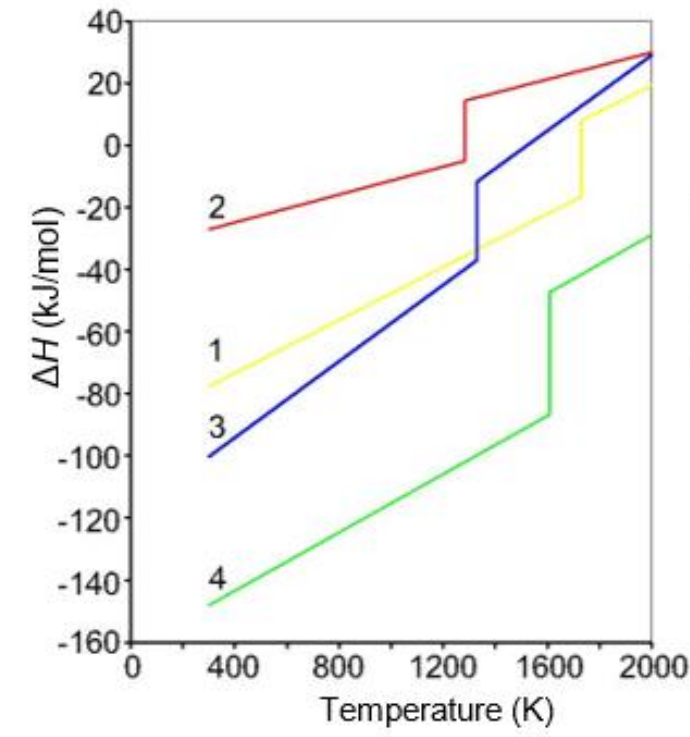

a

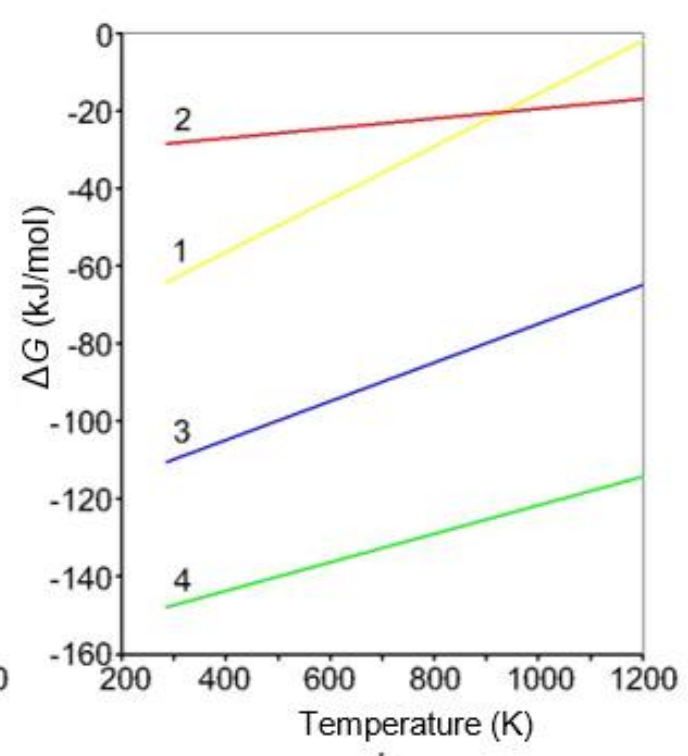

b

Figure 1 Results of calculations of thermodynamic properties of the Ti-Al intermetallic system: a - enthalpy; b - Gibbs energy; 1 - TiAl; $2-\mathrm{TiAl}_{2} ; 3-\mathrm{TiAl}_{3} ; 4-\mathrm{Ti}_{3} \mathrm{Al}$

A relatively cheap way to obtain Ti-Al alloys is the reduction of $\mathrm{TiO}_{2}$ with aluminum in an electric arc furnace $[6,7]$. The Figure 2 shows a diagram of an electric furnace for producing titanium-based alloys containing aluminum.

The main reaction of the aluminothermal process is the following reaction:

$3 \mathrm{TiO}_{2}+4 \mathrm{Al}=3 \mathrm{Ti}+2 \mathrm{Al}_{2} \mathrm{O}_{3}$

The raw material used was titanium slag of experimental heats of the following average composition in wt\%: $70-\mathrm{TiO}_{2}, 14-\mathrm{CaO}, 3-\mathrm{FeO}, 4-\mathrm{SiO}_{2}, 2-\mathrm{Al}_{2} \mathrm{O}_{3}, 3-\mathrm{MgO}, 2-\mathrm{MnO}, 1-\mathrm{V}_{2} \mathrm{O}_{5}, 1$ - others. The charge was a 
mixture of crushed slag to pieces of 0.1-0.2 mm in size, $\mathrm{Al}$ - powder, $\mathrm{CaO}$ and $\mathrm{CaF}_{2}$. The latter played the role of a flux, which formed low-melting eutectics with $\mathrm{Al}_{2} \mathrm{O}_{3}$ and thus reduced the melting temperature and viscosity of the slag.

The smelting hearth had an inner diameter of $300-400 \mathrm{~mm}$. In the lower part of the hearth, there was a taphole for tapping slag into a steel mold. The hearth is collapsible, which facilitated the extraction of metal from it. The graphite electrode (150 $\mathrm{mm}$ in diameter) and the hearth had current leads. The furnace power was controlled by switching the voltage of the transformer from / to $V$ stages, as well as by raising and lowering the electrode.

The charge was loaded from the bunker continuously or in small portions while the electric load of the furnace was switched on. In this case, an aluminothermic reaction took place in the smelting hearth (1). The charge weight for melting was $100-200 \mathrm{~kg}$, the melting time was $10-20$ minutes. After the entire charge had been melted, the electrode was raised to the upper position, the taphole was opened, and the slag melt was poured into the riser. The metal remained in the hearth and, after cooling, was removed from it.

The ratio of the charge loading rate $(v, \mathrm{~kg} / \mathrm{min})$ to the surface power density per area unit of the furnace hearth $\left(q, \mathrm{MVA} / \mathrm{m}^{2}\right)$ was maintained within $v / q=10-12$, which ensured good melting of the charge and separation of metal and slag : slag was poured out of the hearth, and the metal remained in it in the form of a compact ingot.

The approximate average composition of the metal obtained from titanium slag is as follows, wt\%: Ti- $60, \mathrm{Fe}$ $5, \mathrm{Si}-3, \mathrm{Mn}-2, \mathrm{Cr}-1, \mathrm{~V}-0.5, \mathrm{C}-0.4, \mathrm{~S}-0.04$, the rest is Al. Due to the fact that the titanium slag contained many impurities, the resulting alloy also contained many impurities. In laboratory conditions, pigment $\mathrm{TiO}_{2}$ was used as a component of the charge, and an alloy containing $78 \% \mathrm{Ti}$, the rest being $\mathrm{Al}$, was obtained. $\mathrm{Ti}$ - slag of ZTMK or cheaper metallurgical titanium dioxide can be used as a raw material.

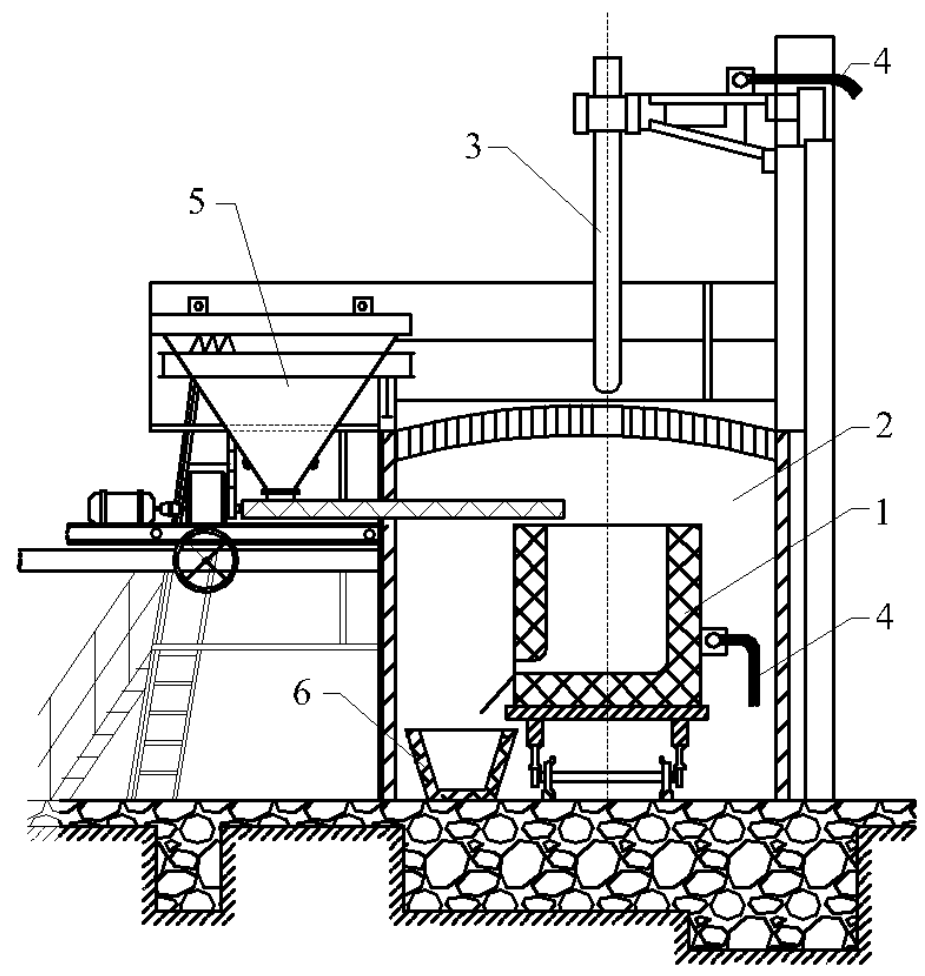

Figure 2 Diagram of an electric furnace for producing Ti-Al alloys: 1 - graphite melting hearth, 2 - melting chamber, 3 - graphite electrode, 4 - current leads, 5 - charge tank, 6 - slag mould

Also, a theoretical study of the possibility of obtaining high-percentage ferrotitanium ( $65-75 \mathrm{wt} \% \mathrm{Ti}$ ) by reducing $\mathrm{TiO}_{2}$ with magnesium powder was made. It is known that titanium dioxide is not completely reduced by magnesium, the resulting product contained $92 \% \mathrm{Ti}$, the rest is apparently lower titanium oxides. 
We carried out a thermodynamic assessment of the possibility of a magnesium-thermal reaction of $\mathrm{TiO}_{2}$ reduction in the presence of iron powder:

$\mathrm{TiO}_{2}+2 \mathrm{Mg}+0.37 \mathrm{Fe}=\mathrm{Ti}+0.37 \mathrm{Fe}+2 \mathrm{MgO}$

$\mathrm{Ti}+0.37 \mathrm{Fe}$ is FeTi70 ferrotitanium. Thermodynamic modeling was carried out using the TERRA program. The initial data and calculation results are shown in Figure 3. The obtained data show that reaction (2) can be carried out up to a temperature of $1500 \mathrm{~K}$; at a higher temperature, the lower oxide TiO begins to form. At temperatures of $1700 \mathrm{~K}$ and higher, metallic titanium is absent, only $\mathrm{TiO}$ is present.

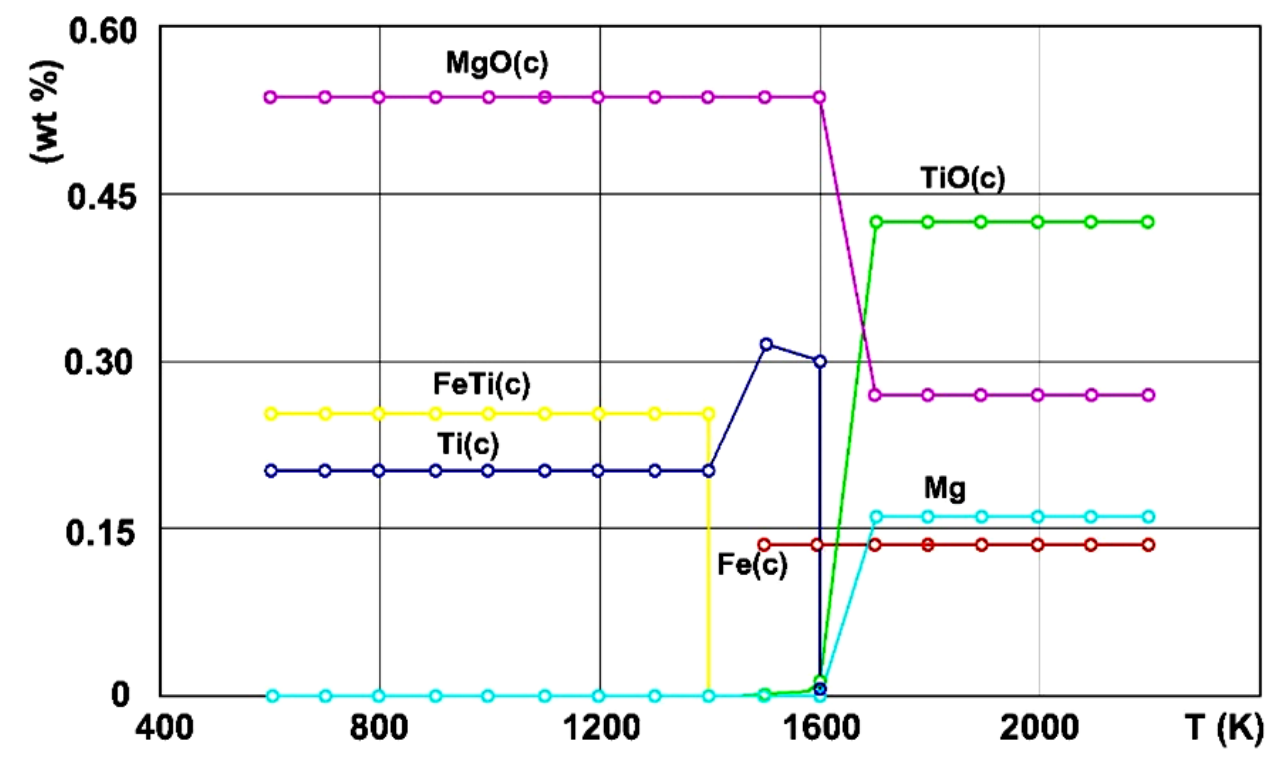

Figure 3 The results of calculating the possibility of the reaction

High-percentage ferrotitanium has a melting point of $1358 \mathrm{~K}$ [4]; therefore, in order to obtain an alloy in a liquid state, reaction (2) must be carried out in a narrow temperature range of $1400-1500 \mathrm{~K}$. A suspension of $\mathrm{MgO}$ particles from the Ti-Fe melt can be separated by extrusion [14].

\section{CONCLUSION}

The high cost of commercial titanium alloys used in products for aerospace, military and medical purposes prompts manufacturers to search for ways to obtain alloys for civilian use, which are not so high purity in terms of impurity content, but which have lower cost. Methods for producing titanium in the form of alloys with aluminum and iron by metallothermic reduction of titanium-containing oxide raw materials are considered. It is shown that these alloys can be successfully used in many areas of industry, under conditions of a decrease in the amount of titanium waste, which is obtained by traditional chloride technology.

\section{REFERENCES}

[1] APPEL, F., HEATON PAUL, J. D., OEHRING, M. Gamma Titanium Aluminide Alloys: Science and Technology. Weinheim: Wiley-VCH Verlag GmbH, 2011.

[2] PAVLENKO, D.V., BELOKON', Y.O., TKACH, D.V. Resource-saving technology of manufacturing of semifinished products from intermetallic $\mathrm{Y}$-TiAl alloys intended for aviation engineering. Materials Science. 2020, vol. 55, no. 6, pp. 908-914.

[3] ZABELIN, I.V., PROTSENKO, V.M. Status of non-ferrous metal industry in Ukraine and problems in its development. Metallurgicheskaya i Gornorudnaya Promyshlennost. 2003, vol. 4, pp. 75-78. 
[4] BELOKON, K., BELOKON, Y. The usage of heat explosion to synthesize intermetallic compounds and alloys. Ceramic Transactions. 2018, vol. 261, pp. 109-115.

[5] SEREDA, B., SEREDA, D., BELOKON, Y. Investigation of corrosion and oxidation of Y-TiAl alloys obtained in self propagating high temperature synthesis. In: Materials Science and Technology Conference and Exhibition.

Columbus: MS\&T, 2015, pp. 1249-1255.

[6] SEREDA, B., KRUGLYAK, I., ZHEREBTSOV, A., SHEYKO, S., BELOKON', Y. The modelling of products pressing in SHS-systems. In: Materials Science and Technology. Pittsburgh: MS\&T, 2008, pp. 827-831.

[7] CHEYLYTKO, A. A study of the rates of pore nucleation and pore growth in alumina-based thermal insulation materials. East. Europ. J. Enterprise Technol. 2016, vol. 2, no. 8, pp. 56-62.

[8] PAVLENKO, A., CHEILYTKO, A., ILIN, S., KOSHLAK, H. Porous structures and their effect on thermophysical properties of thermal protection elements. Solid State Phenomena. 2019, vol. 291, pp. 20-27.

[9] SEREDA, B., SHEYKO, S., BELOKON, Y., SEREDA, D. The influence of modification on structure and properties of rapid steel. In: AIST Steel Properties and Applications Conference Proceedings - Combined with MS and T'11, Materials Science and Technology. Columbus: MS\&T, 2011, pp. 457-460.

[10] SEREDA, B., BELOKON, Y., BELOKON, K., KRUGLYAK, I., SEREDA, D. Thermodynamics analysis of flowing for SHS-reactions in system Ni-Al alloys. In: Materials Science and Technology Conference and Exhibition. Portland: MS\&T, 2019, pp. 1395-1400.

[11] CHEILYTKO, A.A., ILIN, S.V., NOSOV, M.A. Creation of effective metallic thermal insulation constructions. Naukovyi Visnyk Natsionalnoho Hirnychoho Universytetu. 2017, no. 6, pp. 103-108.

[12] BEYGELZIMER, Y. E., PAVLENKO, D. V., SYNKOV, O. S., DAVYDENKO, O. O. The efficiency of twist extrusion for compaction of powder materials. Powder Metallurgy Metal Ceram. 2019, vol. 58, no. 1-2, pp. 7-12.

[13] BELOKON, K. V., BELOKON, Y. A., KOZHEMYAKIN, G. B., MATUKHNO, E. V. Environmental assessment of the intermetallic catalysts utilization efficiency for deactivation of the pollutants emitted by electrode production enterprises. Naukovyi Visnyk Natsionalnoho Hirnychoho Universytetu. 2016, no. 3, pp. 87-94.

[14] HRUDKINA, N., ALIIEVA, L., MARKOV, O., MARCHENKO, I., SHAPOVAL, A., ABHARI, P., KORDENKO, M. Predicting the shape formation of hollow parts with a flange in the process of combined radial-reverse extrusion. Eastern-European Journal of Enterprise Technologies. 2020, vol. 4/1, no. 106, pp. 55-62. 